he is buried solely on the pleas of an arch enemy (Odysseus) who only performs this role because his morality is one of 'generalised mutuality', ${ }^{41}$ radically different from his own morality, and his posthumous honour comes again from Odysseus by whom he would not have cared to be honoured.

\title{
EDITORIAL NOTES
}

Ian McAuslan is stepping down after twenty-eight years editorial service to Greece \& Rome and New Surveys in the Classics. Ian's contribution to the flourishing of the Association's publications has been immense, and his wise guidance will be much missed. We are very grateful to him. Dr John Taylor is to succeed Ian as Editor with responsibility for New Surveys.

Richard Hunter

Chair, Classical Association Journals Board

The editors would like to express their sincere and warm gratitude to Stephen Halliwell, whose other commitments are, with this issue, bringing to an end a long and greatly valued role as Greek Literature reviewer for this journal. Over the course of nineteen consecutive issues of the journal, spanning almost a decade, Stephen has brought a combination of wide-ranging erudition and good humour to his insightful reviews of a staggering total of 244 books, much to the benefit of our readers. We are delighted to announce that Malcolm Heath of the University of Leeds will be Stephen's successor.

should succeed in burying him against the order of the generals, his status will remain unrecognised': Garvie (n. 18), $235 f$.

${ }^{41}$ Meier (n. 18), 174. 'It is ironical that that Ajax will secure his burial only because Agamemnon will accept the obligation which Ajax had rejected for himself': Garvie (n. 18), ad 1353. 'Odysseus is prepared to do for Ajax what Ajax declined to do (522) even for Tecmessa, and what Agamemnon's failure to do was lamented by Teucer (1266-7)': ibid., ad 1354-6. '. . Odysseus' generosity represents the crowning form of eugeneia in the Ajax ... it is Odysseus' combination of the sense of justice and the conditioning factor of emotional responses like pity which finally succeeds in resolving the quarrel over Achilles' armour in the last stages': Zanker (n. 15), 25. 